\title{
KETIMPANGAN AKSES TERHADAP TEKNOLOGI INFORMASI DENGAN PENDEKATAN HUMAN OPPORTUNITY INDEX (HOI)
}

\author{
(INEQUALITY OF ACCESS TO INFORMATION TECHNOLOGY WITH HUMAN OPPORTUNITY \\ INDEX (HOI) APPROACH)
}

\author{
Riyadi $^{1}$, Putri Larasaty ${ }^{2}$ \\ Direktorat Analisis dan Pengembangan Statistik, BPS ${ }^{1}$ \\ Direktorat Analisis dan Pengembangan Statistik, BPS ${ }^{2}$ \\ Jalan dr. Sutomo No. 6-8 Jakarta \\ E-mail: riyadi@bps.go.id
}

\begin{abstract}
ABSTRAK
Ketimpangan merupakan salah satu permasalahan utama yang mungkin belum dapat tuntas diatasi. Penelitian ini menganalisis ketimpangan kesempatan dalam mengakses layanan teknologi dan informasi di Indonesia. Data yang digunakan dalam penelitian ini berasal dari SUSENAS Kor tahun 2019 dari BPS. Analisis ini menggunakan metode Human Opportunity Index (HOI) yang dikembangkan oleh Bank Dunia. HOI menghitung peranan dari masing-masing keadaan sosial ekonomi dan demografi individu terhadap ketimpangan kesempatan dalam mengakses layanan teknologi dan informasi. Selain itu, model logit digunakan untuk mengetahui pengaruh faktor sosial ekonomi dan demografi terhadap akses memperoleh layanan teknologi dan informasi. Hasil analisis empiris menunjukkan bahwa ketimpangan kesempatan akses terhadap layanan teknologi dan informasi di Kawasan Indonesia Timur dan Kawasan Indonesia Barat masih cukup lebar. Selain itu, kondisi pengeluaran per kapita dan daerah tempat tinggal menjadi faktor yang dominan berpengaruh terhadap ketimpangan ketimpangan kesempatan akses terhadap layanan teknologi dan informasi. Ini menunjukkan bahwa kemiskinan rumah tangga dan daerah tempat tinggal mempunyai peranan yang penting dalam menentukan akses yang setara dalam akses terhadap teknologi dan informasi.
\end{abstract}

Kata kunci: ketimpangan kesempatan, teknologi informasi, HOI, model logistik

\begin{abstract}
Inequality is one of the crucial problems that may not be completely resolved. This study analyzes the inequality of opportunities in accessing technology and information services in Indonesia. The data used in this study from the 2019 SUSENAS KOR from Statistics Indonesia-BPS. This analysis uses the Human Opportunity Index (HOI) method developed by the World Bank. HOI calculates the contribution of each individual's socio-economic and demographic conditions on the inequality of opportunities in accessing technology and information services. In addition, the logit model is used to determine the influence of socioeconomic and demographic factors on access to technology and information services. The results of empirical analysis show that the inequality of access to technology and information services in Eastern Indonesia and West Indonesia is still quite wide. In addition, conditions of per capita expenditure and area of residence are the dominant factors affecting the inequality of opportunities in access to technology and information services. This shows that the poverty of households and areas of residence has an important role in determining equal access to access to technology and information.
\end{abstract}

Keywords: inequality of opportunity, information technology, HOI, logistik model

\section{PENDAHULUAN}

Tujuan Pembangunan Berkelanjutan yang menjadi agenda pembangunan global hingga tahun 2030 memiliki prinsip pencapaian pembangunan yang inklusif, yaitu tidak meninggalkan satu orangpun (leave no one behind). Pengurangan kesenjangan menjadi salah satu komponen utama 
yang difokuskan dalam tujuan pembangunan berkelanjutan. Selain untuk peningkatan kesejahteraan rakyat, pembangunan harus dilakukan secara merata, sehingga hasil pembangunan dapat dinikmati seluruh lapisan masyarakat.

Namun, tentunya kita menyadari masih terdapat masalah ketimpangan di tengah-tengah masyarakat. Ketimpangan yang tinggi akan mengakibatkan terjadinya inefisiensi ekonomi dan melemahkan stabilitas sosial (Todaro \& Smith, 2011). Pada awalnya, konsep keadilan adalah kesetaraan yang berdasarkan pada distribusi outcome. Dalam perkembangannya, teori yang digagas oleh Rawls (1971) dalam Theory of Justice, keadilan telah mempertimbangkan kesetaraan dalam proses. yaitu bagaimana hasil akhir ditentukan oleh kesempatan yang diperoleh individu dan pemanfaatan kesempatan tersebut oleh tiap individu. Dworkin (1981) juga menyatakan bahwa keadilan diukur dari kesetaraan sumber dayanya, bukan dari segi outcomes. Selanjutnya, Sen dan Hawthorne (1985) dalam Indra (2015) mengasosiasikan kesetaraan dengan "equality of something', bukan pada outcomes. Arneson (1989) juga menjelaskan kesetaraan kesempatan menjadi fokus utama untuk mencapai kesejahteraan, bukan kesejahteraan itu sendiri.

Beberapa literatur telah membahas faktor yang dapat menyebabkan terjadinya perubahan ketimpangan. Menurut UNDP (2014), perubahan ketimpangan disebabkan oleh faktor eksogenous dan endogenous. Faktor eksogenus yang memengaruhi ketimpangan yaitu arus globalisasi perdagangan dan keuangan serta kemajuan teknologi. Sementara itu, faktor endogenus yang menyebabkan ketimpangan antara lain kekayaan, kebijakan fiskal seperti pajak dan transfer, serta pengeluaran pemerintah untuk barang-barang publik. Selain itu, De Soto (2000) menyatakan bahwa ketimpangan terjadi karena buruknya sistem kepemilikan aset.

Selanjutnya, De Barros, dkk. (2009) menyebutkan bahwa ketimpangan terjadi karena adanya ketimpangan dalam kesempatan (inequality of opportunity), ketimpangan dalam usaha yang berasal dari faktor intrinsik individu sendiri, dan kebijakan pemerintah. Selain itu, terdapat faktor penghambat seseorang dalam mengakses kebutuhan yang tidak dapat dikendalikan oleh seseorang yaitu faktor demografis orang tersebut seperti jenis kelamin, suku, tempat kelahiran, atau latar belakang keluarga. Menurut Indra (2015), penurunan ketimpangan hendaknya berfokus melalui ketimpangan kesempatan bukan melalui ketimpangan outcome, yang sering diukur melalui "ketimpangan pendapatan". Menurunkan ketimpangan kesempatan mempunyai makna mengupayakan kesetaraan kesempatan masyarakat dalam pemenuhan kebutuhan dasar dan memperhatikan pemerataan distribusi kebutuhan dasar tersebut.

\section{Residual Inequality \\ (Usaha, pilihan, dan \\ keberuntungan individu)}

\section{Inequality of Condition}

(Jenis kelamin, ras, keluarga, endidikan orang tua, jumlah

anak, sumber daya keluarga, lokasi, dan lain lain)

\section{Inequality of Opportunity in Access to Basic Services \\ (Pendidikan, kesehatan, infrastruktur, sanitasi, listrik, dan lain lain)}

Sumber: Ringkdsan dari De Barkos, dkk (2009) dalam Indra (2015)

Gambar 1. Diagram Sumber Ketimpangan

Secara umum, ketimpangan kesempatan merupakan sulitnya sebagian orang dalam mendapatkan kesempatan untuk dapat hidup yang lebih baik di bidang sosial maupun ekonomi. Ketimpangan kesempatan dapat mencakup segala aspek, seperti pendidikan, kesehatan, 
pendapatan, dan digital atau teknologi informasi. Ketimpangan digital atau teknologi informasi sangat berpengaruh pada tingkat kesejahteraan dan terjadinya ketimpangan sosial dan ekonomi lainnya. Todaro \& Smith (2011) menyatakan bahwa kemajuan teknologi adalah salah satu komponen yang berpengaruh terhadap pertumbuhan ekonomi. Dalam studinya, DiMaggio \& Garip (2012) menjelaskan bahwa ketidaksetaraan digital akan menimbulkan atau memperparah ketidaksetaraan sosial karena keberadaan teknologi informasi berperan pada peningkatan modal manusia.

Beberapa penelitian yang telah dilakukan dalam menghitung ketimpangan akses layanan teknologi informasi antara lain oleh Sutton (1991) dan Kemenppa \& BPS (2019). Dalam penelitiannya, Sutton (1991) meneliti mengenai pengunaan komputer di sekolah dan menemukan bahwa terdapat kesenjangan dalam hal akses, tipe penggunaan dan kompetensi komputer oleh siswa. Hal yang menjadi penyebab ketimpangan tersebut antara lain jenis kelamin, ras dan kelas sosial dari siswa. Sementara itu, Kemenppa \& BPS (2019) meneliti mengenai ketimpangan anak dalam memenuhi kebutuhan penggunaan komputer dan internet. Hasilnya menyatakan bahwa peluang akses dan HOI akses penggunaan pc/laptop/komputer lebih kecil dibandingkan akses internet, ketimpangan kesempatan terhadap penggunaan pc/laptop/komputer lebih besar daripada akses internet. Selain itu, akses penggunaan laptop/komputer/pc dan internet dipengaruhi faktor pengeluaran per kapita, daerah tempat tinggal, dan pendidikan KRT.

Penelitian ini bertujuan untuk menganalisis ketimpangan kesempatan dalam mengakses layanan Teknologi dan Informasi (TI) di Indonesia. Menurut Kominfo (2014), perkembangan TI dapat memberikan banyak manfaat untuk kesejahteraan masyarakat dalam segala bidang kehidupan mulai dari bidang bisnis, sosial, bahkan bidang teknologi. Teknologi mampu memudahkan masyarakat melakukan bisnis dan menjalin hubungan sosial antar individu. TI juga dapat menjadi sarana untuk mewujudkan bangsa yang cerdas dan maju karena di dalam tekonologi termasuk di dalamnya internet, dapat memberikan manfaat besar bagi pendidikan, penelitian, niaga, dan aspek kehidupan lainnya. Bagi dunia pendidikan, TI dapat meningkatkan pengetahuan, dan memperluas kesempatan serta keberdayaan dalam meraih kualitas kehidupan yang lebih baik. Oleh karena itu, kebutuhan akan TI dapat dikatakan cukup penting.

\section{METODE}

\section{Data dan Sumber Data}

Penelitian ini menggunakan data dari Susenas Kor Maret 2019 dari BPS. Cakupan responden yang digunakan pada penelitian ini hanya pada pemuda yaitu penduduk berumur 16-30 tahun. Hal ini disebabkan di jaman seperti sekarang ini, akses layanan teknologi informasi dan komunikasi lebih cenderung banyak dinikmati oleh kaum muda. Batasan akses layanan teknologi informasi dan komunikasi yang dibahas dalam penelitian ini disesuaikan dengan ketersediaan data pada Susenas. Akses tersebut yaitu penggunaan handphone, penggunaan PC/komputer/laptop, dan akses penggunaan internet.

Variabel penelitian yang akan digunakan dalam penelitian ini yaitu jenis kelamin individu, daerah tempat tinggal, jenis kelamin Kepala Rumah Tangga (KRT), pendidikan KRT, status bekerja $\mathrm{KRT}$, jumlah ART, pengeluaran per kapita RT, penggunaan handphone, kepemilikan handphone, penggunaan $\mathrm{PC} /$ komputer/laptop dan penggunaan internet.

Tabel 1. Deskripsi Variabel yang Digunakan dalam Penelitian.

\begin{tabular}{ll}
\hline \multicolumn{1}{c}{ Variabel } & \multicolumn{1}{c}{ Keterangan } \\
\hline Jenis kelamin individu & Bernilai 0 jika perempuan, berilai 1 jika laki-laki \\
Daerah tempat tinggal & Bernilai 0 jika perdesaan, bernilai 1 jika perkotaan \\
Jenis kelamin KRT & Bernilai 0 jika perempuan, bernilai 1 jika laki-laki \\
Ijazah KRT & Bernilai 0 jika pendidikan tertinggi SMP ke bawah, bernilai 1 jika \\
Status bekerja KRT & pendidikan tertinggi SMA ke atas \\
Pengeluaran per kapita RT & Bernilai 0 jika tidak bekerja, bernilai 1 jika bekerja
\end{tabular}


Jumlah ART

Penggunaan HP

Kepemilikan HP

Penggunaan PC

Penggunaan Internet

Kawasan Indonesia
Jumlah anggota rumah tangga

Bernilai 0 jika tidak menggunakan HP, bernilai 1 jika menggunakan $\mathrm{HP}$

Bernilai 0 jika tidak memiliki HP, bernilai 1 jika memiliki HP

Bernilai 0 jika tidak menggunakan PC/komputer/laptop, bernilai 1

jika menggunakan PC/komputer/laptop

Bernilai 0 jika tidak menggunakan internet, bernilai 1 jika tidak

menggunakan internet

Bernilai 0 jika Kawasan Barat Indonesia/KBI, bernilai 1 jika Kawasan Timur Indonesia/KTI

\section{Metode Human Opportunity Index (HOI)}

Ketimpangan akses layanan teknologi informasi dan komunikasi diukur dengan dengan menggunakan metode Human Opportunity Index (HOI) yang dikembangkan oleh World Bank. HOI dapat berfungsi sebagai alat bantu dalam mengarahkan kebijakan publik yang bertujuan untuk menyetarakan peluang atau kesempatan (Indra, 2015). HOI mengukur ketimpangan kesempatan melalui indikator yang menggabungkan dua elemen yaitu (i) tingkat cakupan (coverage) peluang dasar dan (ii) sejauh mana distribusi peluang tersebut dipengaruhi oleh keadaan eksogen pada individu (circumtances). Keadaan eksogen tersebut seperti jenis kelamin, pendapatan, atau karakteristik rumah tangga. Semakin tinggi nilai coverage pemenuhan akses maka akan semakin tinggi pula nilai HOI-nya. Apabila dalam hal meningkatkan coverage diikuti dengan meratanya distribusi pemenuhan akses tersebut ke kelompok masyarakat yang kurang beruntung (masyarakat terpencil atau masyarakat miskin), maka akan terjadinya penurunan nilai ketimpangan dan memperbesar nilai HOI.

Menurut Indra (2015), penghitungan HOI akan dapat memberikan tiga nilai komponen yaitu nilai HOI itu sendiri, nilai coverage, dan nilai kemerataan distribusi. Nilai coverage diestimasi melalui model logistik, sementara nilai kemerataan distribusi dihitung dengan menggunakan formulasi tertentu dan mempertimbangkan hasil dari komponen coverage. Nilai HOI $(\mathrm{H})$ itu sendiri dinyatakan dalam suatu ukuran skalar. Nilai HOI akan meningkat ketika nilai rata-rata coverage meningkat, tetapi nilai HOI akan menurun ketika terdapat perbedaan coverage pada tiap kelompok dengan berbagai set keadaan (circumstances).

Pengukuran kemerataan atau ketimpangan kesempatan dinyatakan sebagai nilai dari Dissimilarity Index (D). Indeks D menghitung berapa perbedaan tingkat akses pemenuhan kebutuhan pada suatu set kelompok dengan keadaan tertentu (misalnya jenis kelamin, daerah tempat tinggal, pendidikan orang tua, dan sebagainya) dibandingkan dengan rata-rata tingkat akses pemebuhan kebutuhan secara keseluruhan. Nilai Indeks D ini juga dapat disebut sebagai share dari total kesempatan yang perlu direalokasi pada kelompok-kelompok dengan berbagai keadaan agar dapat memastikan setiap kelompok mempunyai tingkat akses yang sama (Indra, 2015).

Dalam persamaannya, HOI dapat dinyatakan sebagai berikut.

$$
H=\bar{p}(1-D) ; H \leq \bar{p}<100 \text { dan } H \leq D \leq 100
$$

dimana,

$$
\begin{aligned}
& \mathrm{H}=\text { nilai } \mathrm{HOI} \\
& \bar{p}=\text { rata-rata coverage } \\
& \mathrm{D}=\text { nilai ketimpangan (dissemilarity index) }
\end{aligned}
$$

HOI dapat bernilai 100 apabila memenuhi persayaratan akses bersifat universal terpenuhi, dimana nilai $\bar{p}$ sama dengan 100 dan nilai $\mathrm{D}$ sama dengan nol. Dengan kata lain, HOI dapat diartikan sebagai peluang atau kesempatan akses yang dimiliki masyarakat yang telah terdistribusi dengan prinsip kesetaraan. Pembuat kebijakan mempunyai pandangan bahwa perlu untuk meningkatkan coverage dan menimalkan tingkat ketimpangan.

De Barros, dkk. (2009) mendefiniskan indeks D sebagai jumlah rata-rata terbobot dari perbedaan absolut antara tingkat akses individu dalam kelompok-i $\left(p_{i}\right)$ dengan tingkat akses ratarata seluruh populasi $(\bar{p})$. Rumus dalam persamaannya sebagai berikut. 


$$
D=\frac{1}{2 \bar{p}} \sum_{i=1}^{n} \alpha_{i}\left|p_{i}-\bar{p}\right|
$$

dimana,

$\mathrm{i}=$ kelompok individu yang berada pada set keadaan tertentu

$p_{i}=$ tingkat coverage dari kelompok ke-i

$\alpha_{i}=$ bobot yang menyatakan share dari jumlah individu yang berada pada kelompok-i terhadap

total populasi

$\mathrm{n}$ =jumlah kelompok yang terbentuk berdasarkan keadaan

Indeks $D$ berada di rentang 0 hingga 100 . Pada saat nilai $D$ sama dengan 0 , berarti akan terjadi tingkat kesempatan yang setara (perfect equality) karena nilai dimana $\bar{p}=p_{i}$ untuk setiap i.

Menurut De Barros, dkk. (2009), langkah-langkah yang dilakukan untuk menghitung nilai estimasi HOI sebagai berikut.

1. Estimasi peluang penduduk pada kelompok dengan set keadaan tertentu, mendapatkan akses ke kebutuhan tertentu, menggunakan model logistik. Akses yang dimaksud dalam penelitian ini yaitu akses teknologi informasi dan komunikasi (handphone, komputer dan internet). Kebutuhan ini dinyatakan sebagai fungsi yang melekat pada individu sesuai karakteristiknya. Karakteristik yang melekat tersebut antara lain jenis kelamin individu, daerah tempat tinggal, jenis kelamin KRT, pendidikan KRT, status pekerjaan KRT, jumlah anggota rumah tangga, dan pengeluaran perkapita rumah tangga. Pada tahap ini menghasilkan nilai peluang bersyarat dari akses terhadap kebutuhan layanan teknologi informasi dan komunikasi berdasarkan karakteristik yang melekat atau disimbolkan dengan $\widehat{p}_{i}$.

2. Menghitung nilai prediksi bagi tingkat coverage rata-rata $(\hat{\bar{p}})$ dan dissimilarity index $(\widehat{D})$ dengan dengan menggunakan hasil prediksi peluang $\left(\widehat{p}_{\imath}\right)$ dan sample weights $\left(w_{i}=1 / n\right)$. Rumus menghitung $\hat{\bar{p}}$ dan $\widehat{D}$ adalah sebagai berikut.

$$
\begin{array}{r}
\hat{\bar{p}}=\sum_{i=1}^{n} w_{i} \widehat{p}_{l} \ldots \ldots . \\
\widehat{D}=\frac{1}{2 \overline{\bar{p}}} \sum_{i=1}^{m} w_{i}\left|\widehat{p}_{l}-\hat{\bar{p}}\right|
\end{array}
$$

3. Menghitung nilai HOI dengan formula sebagai berikut.

$$
\widehat{H}=\hat{\bar{p}}(1-\widehat{D}) \text {. }
$$

Dalam penghitungan HOI, juga dapat dihitung juga dekomposisi ketimpangan kesempatan. Seperti diketahui sebelumnya, nilai Indeks $D$ dihitung dari suatu himpunan keadaan. Dari himpunan keadaan tersebut dapat dihitung kontribusi marjinal dari masing-masing keadaan terhadap ketimpangan kesempatan. Oleh karena itu, untuk menghitung dekomposisi ketimpangan dapat menggunakan metode Dekomposisi Shapley. De Barros, dkk. (2009) dalam Indra (2015) menyatakan bahwa setiap penambahan variabel kondisi akan meningkatkan indeks $D$ atau menurunkan HOI. Sebagai gambaran, jika terdapat dua set kondisi, $A$ dan $B$ yang keduanya tidak overlap, maka $D(A, B) \geq D(A)$, sehingga $\operatorname{HOI}(A, B) \leq H O I(A)$. Dengan demikian, dampak dari penambahan kondisi $A$ pada suatu set kondisi tertentu $(S)$ dinyatakan sebagai berikut.

$$
D_{A}=\sum_{S \sqsubseteq N / A} \frac{|s| !(n-|s|-1) !}{n !}[D(S \cup\{A\})-D(S)]
$$

dimana,

$\mathrm{N} \quad=$ set dari semua kondisi yang mungkin dari total $\mathrm{n}$ kondisi.

$\mathrm{S} \quad=$ himpunan bagian dari $\mathrm{N}$ (terdiri dari s kondisi), tetapi tidak mengandung kondisi $\mathrm{A}$.

$\mathrm{D}(\mathrm{S}) \quad=$ menyatakan indeks perbedaan dari set kondisi $\mathrm{S}$.

$\mathrm{D}(\mathrm{SU}\{\mathrm{A}\})=$ indeks perbedaan yang dihitung berdasarkan set kondisi $\mathrm{S}$ dan kondisi $\mathrm{A}$.

Dengan demikian penghitungan kontribusi dari kondisi $A$ terhadap indeks ketimpangan dari seluruh kondisi $\left(\theta \_A\right)$ dinyatakan dengan formula berikut.

$$
\theta_{A}=\frac{D_{A}}{D(N)} ; \sum_{i e n} \theta_{i}=1
$$




\section{Teknik Analisis Data}

Metode analisis yang digunakan yaitu analisis deskriptif dan analisis inferensia. Analisis deskriptif digunakan untuk melihat seberapa besar tingkat kesempatan dan ketimpangan kesempatan pemuda dalam mengakses layanan teknologi informasi dan komunikasi seperti handphone, pc/komputer/laptop dan internet. Sementara itu, analisis inferensia menggunakan model regresi logistik untuk mengetahui pengaruh faktor sosial ekonomi dan demografi terhadap akses internet. Dependent variable dalam penelitian ini adalah status penggunaan internet, sedangkan independent variable yaitu jenis kelamin individu, daerah tempat tinggal, jenis kelamin Kepala Rumah Tangga (KRT), pendidikan KRT, status bekerja KRT, jumlah ART, pengeluaran per kapita RT, penggunaan handphone, kepemilikan handphone, dan penggunaan PC/komputer/laptop. Menurut Setiawati \& Utomo (2017), regresi logistik tidak memerlukan asumsi normalitas, heteroskedasitas dan autokeralasi, tetapi tetap dilakukan uji multikolinearitas.

\section{HASIL DAN PEMBAHASAN}

\section{Gambaran Umum Akses Penduduk Berumur 16-30 Tahun terhadap Layanan Informasi Teknologi dan Komunikasi}

Teknologi informasi dan teknologi memegang peranan yang cukup penting bagi generasi muda dalam menghadapi persaingan global di tengah era industri 4.0. Hendaknya setiap generasi muda mempunyai kesempatan yang sama dalam memanfaatkan berbagai sarana teknologi informasi dan komunikasi dalam rangka pengembangan diri demi peningkatan kualitas sumber daya manusia dan pada akhirnya meningkatkan kesejahteraan masyarakat. Menurut data BPS dari Susenas dapat ditunjukkan bahwa peluang akses (coverage) penggunaan handphone pada pemuda berumur 16-30 tahun mencapai 93,78 persen dan dengan nilai HOI sebesar 91,78 persen. Artinya, sekitar 92 persen kesempatan akses penggunaan handphone telah dialokasikan dengan prinsip kesetaraan. Sementara itu, nilai indeks ketimpangan kesempatan akses penggunaan handphone sebesar 2,12 persen, atau masih terdapat sekitar 2 persen kesempatan akses penggunaan handphone yang perlu dialokasikan untuk menjamin prinsip kesetaraan. Faktor yang berkontribusi dominan pada ketimpangan kesempatan akses penggunaan handphone yaitu pengeluaran per kapita, daerah tempat, dan pendidikan kepala rumah tangga dengan kontibusinya masing-masing sebesar 50,47 persen; 28,98 persen; dan 11,23 persen.

Tabel 2. Nilai HOI, Dissemilarity Index, Coverage, dan Shapley Decomposition Penggunaan Handphone pada Pemuda (Penduduk berumur 16-30 Tahun) Menurut Kawasan Indonesia.

\begin{tabular}{lrrr}
\hline Komponen & KBI & KTI & Total \\
\hline HOI & 93,14 & 86,49 & 91,78 \\
Dissemilarity & 1,80 & 3,58 & 2,12 \\
Coverage & 94,85 & 89,7 & 93,78 \\
\hline Shapley Decomposition & & & \\
$\quad$ Jenis kelamin individu & 3,93 & 1,61 & 2,96 \\
$\quad$ Daerah tempat tinggal & 16,36 & 45,72 & 28,98 \\
$\quad$ Jenis kelamin KRT & 0,27 & 2,68 & 0,81 \\
$\quad$ Ijazah KRT & 17,79 & 4,75 & 11,23 \\
Status bekerja KRT & 1,01 & 4,65 & 2,03 \\
Pengeluaran per kapita RT & 57,14 & 38,82 & 50,47 \\
$\quad$ Jumlah ART & 3,49 & 1,77 & 3,52 \\
\hline
\end{tabular}

Sumber: Susenas KOR Maret 2019 (diolah)

Tabel 2 juga menunjukkan bahwa nilai coverage maupun nilai HOI akses penggunaan handphone di KBI lebih tinggi dibandingkan di KTI. Namun, indeks ketimpangan kesempatan di KTI lebih tinggi dibandingkan di KBI. Ini menunjukkan bahwa kesempatan akses penggunaan 
handphone pada pemuda berumur 16-30 tahun secara merata terjadi di wilayah KBI. Seperti pada level nasional, kontributor terbesar ketimpangan kesempatan akses penggunaan handphone pada pemuda berumur 16-30 tahun baik di wilayah KBI maupun KTI adalah pengeluaran per kapita, daerah tempat tinggal dan pendidikan KRT.

Dari penggunaan PC/komputer/laptop, pada tahun 2019 di kalangan generasi muda (pemuda berumur 16-30 tahun) terlihat mempunyai rata-rata peluang akses (coverage) mencapai 26,27 persen dan dengan nilai HOI sebesar 18,82 persen. Hasil ini menandakan masih rendahnya kesempatan akses penggunaan PC/komputer/laptop pada generasi muda. Nilai HOI ini berarti baru sekitar 19 persen kesempatan akses penggunaan PC/komputer/laptop yang telah dialokasikan dengan prinsip kesetaraan. Sementara itu, nilai indeks ketimpangan kesempatan akses penggunaan PC/komputer/laptop pada pemuda berumur 16-30 tahun tercatat sebesar 28,36 persen Dengan kata lain, masih terdapat sekitar 28 persen kesempatan akses penggunaan $\mathrm{PC} /$ komputer/laptop yang perlu dialokasikan untuk menjamin prinsip kesetaraan.

Untuk melihat faktor apa yang berkontribusi terhadap ketimpangan kesempatan pemuda berumur 16-30 tahun terhadap akses penggunaan PC/komputer/laptop, dapat dilihat pada Tabel 3. Terlihat bahwa pengeluaran per kapita, pendidikan kepala rumah tangga, dan daerah tempat tinggal merupakan kontributor terbesar ketimpangan kesempatan akses penggunaan PC/komputer/laptop pada pemuda berumur 16-30 tahun. Peranan pengeluaran per kapita terhadap terjadinya ketimpangan kesempatan ini yaitu sebesar 43,38 persen, pendidikan kepala rumah tangga sebesar 30,58 persen, dan daerah tempat tinggal sebesar 17,35 persen.

Tabel 3. Nilai HOI, Dissemilarity Index, Coverage, dan Shapley Decomposition Penggunaan PC/Komputer/Laptop pada Pemuda (Penduduk berumur 16-30 Tahun) Menurut Kawasan Indonesia.

\begin{tabular}{lrrr}
\hline Komponen & KBI & KTI & Total \\
\hline HOI & 19,30 & 16,99 & 18,82 \\
Dissemilarity & 27,96 & 30,06 & 28,36 \\
Coverage & 26,79 & 24,30 & 26,27 \\
\hline Shapley Decomposition & & & \\
$\quad$ Jenis kelamin individu & 1,24 & 1,73 & 1,33 \\
$\quad$ Daerah tempat tinggal & 15,67 & 22,43 & 17,35 \\
$\quad$ Jenis kelamin KRT & 0,58 & 1,28 & 0,70 \\
Ijazah KRT & 31,91 & 27,02 & 30,58 \\
Status bekerja KRT & 3,15 & 5,28 & 3,59 \\
Pengeluaran per kapita RT & 44,37 & 39,53 & 43,38 \\
$\quad$ Jumlah ART & 3,09 & 2,73 & 3,07 \\
\hline
\end{tabular}

Sumber: Susenas KOR Maret 2019 (diolah)

Jika dilihat berdasarkan Kawasan Indonesia, baik nilai coverage maupun nilai HOI untuk wilayah KBI selalu lebih tinggi jika dibandingkan wilayah KTI. Namun demikian, indeks ketimpangan kesempatan di wilayah KTI selalu lebih tinggi jika dibandingkan dengan wilayah KBI. Hasil ini mengindikasikan bahwa kesempatan akses penggunaan PC/komputer/laptop pada pemuda berumur 16-30 tahun lebih terdistribusi secara merata di wilayah KBI. Dalam arti lain, kesempatan akses/penggunaan PC/komputer/laptoppada pemuda berumur 16-30 tahun tahun di provinsi wilayah KBI relatif lebih baik dibandingkan di wilayah KTI. Seperti pada level nasional, kontributor terbesar ketimpangan kesempatan akses penggunaan PC/komputer/laptop pada pemuda berumur 16-30 tahun baik di wilayah KBI maupun KTI adalah pengeluaran per kapita, daerah tempat tinggal dan pendidikan KRT.

Selanjutnya, internet juga dapat dikatakan mempunyai peranan yang penting bagi generasi muda dalam upaya untuk saling terhubung satu sama lain. Internet dapat dimanfaatkan untuk saling berbagi dan mendapatkan informasi dan ilmu pengetahuan. Tabel 4 menunjukkan nilai coverage, HOI, dan ketimpangan kesempatan akses internet pada pemuda berumur 16-30 tahun. Nilai coverage dan HOI berturut-turut sebesar 81,22 persen dan 75,15 persen. Nilai HOI 
menunjukkan bahwa hanya sekitar 75 persen kesempatan pemuda berumur 16-30 tahun atas akses internet di Indonesia yang telah dialokasikan berdasarkan prinsip kesetaraan. Sementara itu, nilai indeks ketimpangan sebesar 7,47 persen menunjukkan bahwa sekitar 7 persen kesempatan pemuda berumur 16-30 tahun atas akses internet perlu direalokasi untuk menjamin prinsip kesetaraan. Faktor-faktor yang berkontribusi terbesar terhadap ketimpangan kesempatan akses internet pada pemuda berumur 16-30 tahun adalah pengeluaran per kapita (43,06 persen), daerah tempat tinggal (34,67 persen), dan pendidikan KRT (13,97 persen).

Selanjutnya, HOI dan coverage akses internet juga menunjukkan nilai yang lebih baik terjadi di KBI daripada di KTI. Begitu halnya dengan indeks ketimpangan yang lebih tinggi di KTI daripada di KBI. Oleh karena itu, dapat dikatakan bahwa alokasi kesempatan atau akses terhadap internet pemuda berumur 16-30 tahun lebih merata terjadi di KBI daripada KTI. Masih timpangnya kesempatan akses internet di KBI dan KTI disebabkan adanya kesenjangan infrastruktur antara wilayah KBI dan KTI. Menurut Kemenppa dan BPS (2019) infrastruktur tersebut yaitu ketersediaan Base Transceiver Station (BTS). Walaupun demikian, terdapat faktor lain yang diduga memengaruhi akes internet yaitu biaya yang tinggi yang harus disiapkan untuk mengakses internet seperti untuk pembelian gadget, handphone, atau komputer serta untuk biaya kuota paket data langganan internet. Oleh karena itu, berbagai kebijakan dapat dilakukan oleh pemerintah untuk meningkatkan akses internet. Apabila faktor ketersediaan infrastruktur yang menjadi penyebab utama, maka pemerintah diharapkan perlu membangun infrastruktur teknologi informasi hingga ke pelosok daerah. Langkah lainnya yaitu penyediaan akses internet secara gratis bagi masyrakat sampai dengan wilayah terpencil.

Tabel 4. Nilai HOI, Dissemilarity Index, Coverage, dan Shapley Decomposition Akses Penggunaan Internet pada Pemuda (Penduduk berumur 16-30 Tahun) Menurut Kawasan Indonesia.

\begin{tabular}{lrrr}
\hline Komponen & KBI & KTI & Total \\
\hline HOI & 78,93 & 61,50 & 75,15 \\
Dissemilarity & 6,19 & 12,31 & 7,47 \\
Coverage & 84,14 & 70,13 & 81,22 \\
\hline Shapley Decomposition & & & \\
$\quad$ Jenis kelamin individu & 3,30 & 1,06 & 2,33 \\
$\quad$ Daerah tempat tinggal & 27,82 & 38,09 & 34,67 \\
$\quad$ Jenis kelamin KRT & 0,86 & 1,91 & 1,06 \\
$\quad$ Ijazah KRT & 16,21 & 13,59 & 13,97 \\
Status bekerja KRT & 2,03 & 4,20 & 2,53 \\
Pengeluaran per kapita RT & 47,76 & 39,28 & 43,06 \\
$\quad$ Jumlah ART & 2,01 & 1,87 & 2,38 \\
\hline
\end{tabular}

Sumber: Susenas KOR Maret 2019 (diolah)

\section{Faktor-Faktor yang Berpengaruh pada Akses Penduduk Berumur 16-30 Tahun Terhadap Internet}

Berdasarkan hasil analisis regresi logistik, dengan tingkat kepercayaan 95 persen secara bersama-sama, seluruh independent variable berpengaruh secara signifikan terhadap akses penduduk dalam menggunakan internet. Sementara itu, secara uji parsial diperoleh hasil bahwa seluruh karakteristik sosial ekonomi penduduk berumur 16-30 tahun juga mempunyai pengaruh yng signifikan terhadap akses penggunaan internet. Berdasarkan nilai odds ratio, interpretasi dari besarnya pengaruh dari setiap faktor dalam memengaruhi akses penduduk berumur 16-30 tahun terhadap penggunaan internet sebagai berikut.

1. Jenis kelamin individu (referensi: perempuan). Penduduk laki-laki berumur 16-30 tahun cenderung memiliki akses terhadap penggunaan internet 1,05 kali dibandingkan dengan penduduk perempuan berumur 16-30 tahun. Penduduk laki-laki cenderung memiliki peluang lebih tinggi dalam akses penggunaan internet dibandingkan penduduk perempuan. 
2. Daerah tempat tinggal (referensi: perdesaan). Penduduk berumur 16-30 tahun yang bertempat tinggal di daerah perkotaan cenderung memiliki akses terhadap penggunaan internet 2,31 kali dibandingkan dengan penduduk berumur 16-30 tahun yang bertempat tinggal di daerah perdesaan.

3. Jenis kelamin KRT (referensi: perempuan). Penduduk berumur 16-30 tahun yang KRT-nya berjenis kelamin laki-laki cenderung memiliki akses terhadap penggunaan internet 0,88 kali dibandingkan dengan yang KRT-nya berjenis kelamin perempuan.

4. Ijazah KRT (referensi: SMP ke bawah). Penduduk berumur 16-30 tahun yang KRT-nya mempunyai ijasah SMA ke atas cenderung memiliki akses terhadap penggunaan internet 1,13 kali dibandingkan dengan yang KRT-nya mempunyai ijasah SMP ke bawah.

5. Status bekerja KRT (referensi: tidak bekerja). Penduduk berumur 16-30 tahun yang KRT-nya bekerja cenderung memiliki akses terhadap penggunaan internet 0,82 kali dibandingkan dengan yang KRT-nya tidak bekerja.

6. Pengeluaran per kapita RT. Penduduk berumur 16-30 tahun yang pada rumah tangganya mengalami kenaikan pengeluaran per kapita sebesar 1 persen cenderung memiliki akses terhadap penggunaan internet 2,67 kali dibandingkan dengan penduduk berumur 16-30 tahun yang pada rumah tangganya tidak mengalami kenaikan pengeluaran per kapita. Hasil ini sesuai dengan penelitian Zhu \& He (2002) yang menyebutkan bahwa faktor ekonomi seperti tingkat pendapatan sangat mempengaruhi seseorang dalam menggunakan teknologi dan informasi.

Tabel 5. Hasil Persamaan Regresi Logistik Akses Penggunaan Internet

\begin{tabular}{lcc}
\hline Variabel & \multicolumn{2}{c}{ Akses Internet } \\
\cline { 2 - 3 } & $0,0533^{* * *}$ & Odds Ratio \\
\hline Jenis kelamin individu & $0,8373^{* * *}$ & 1,0548 \\
\hline Daerah tempat tinggal & $-0,1246^{* * *}$ & 2,3102 \\
\hline Jenis kelamin KRT & $0,1276^{* * *}$ & 0,8829 \\
\hline Ijazah KRT & $-0,1989^{* * *}$ & 1,1361 \\
\hline Status bekerja KRT & $0,9820^{* * *}$ & 0,8197 \\
\hline Pengeluaran per kapita RT & $0,0899^{* * *}$ & 2,6697 \\
\hline Jumlah ART & $2,7413^{* * *}$ & 1,0940 \\
\hline Penggunaan HP & $2,4075^{* * *}$ & 15,5065 \\
\hline Kepemilikan & $2,7176^{* * *}$ & 11,1057 \\
\hline Penggunaan PC & $-0,6646^{* * *}$ & 15,1443 \\
\hline Kawasan Indonesia & $-17,2848^{* * *}$ & 0,5144 \\
\hline Konstanta & 0,0000 \\
\hline Keterangan: *** signifikan pada 1\%, ** signifikan pada 5\%, dan * signifikan pada 10\% \\
Sumber: Susenas KOR Maret 2019 (diolah)
\end{tabular}

7. Jumlah ART. Penduduk berumur 16-30 tahun yang pada rumah tangganya mengalami penambahan jumlah ART sebanyak 1 cenderung memiliki akses terhadap penggunaan internet 1,09 kali dibandingkan dengan yang pada rumah tangganya tidak mengalami penambahan jumlah ART.

8. Penggunaan handphone (referensi: tidak menggunakan handphone). Penduduk berumur 1630 tahun yang menggunakan handphone cenderung memiliki akses terhadap penggunaan internet 15,51 kali dibandingkan dengan yang tidak menggunakan handphone.

9. Kepemilikan handphone (referensi: tidak memiliki handphone). Penduduk berumur 16-30 tahun yang memiliki handphone cenderung memiliki akses terhadap penggunaan internet 11,11 kali dibandingkan yang tidak memiliki handphone.

10. Penggunaan PC/komputer/laptop (referensi: tidak menggunakan PC/komputer/laptop). Penduduk berumur 16-30 tahun yang menggunakan PC/komputer/laptop cenderung memiliki akses terhadap penggunaan internet 15,14 kali dibandingkan dengan yang tidak menggunakan PC/komputer/laptop.

11. Kawasan Indonesia (referensi: KBI). Penduduk berumur 16-30 tahun di KTI cenderung memiliki akses terhadap penggunaan internet 0,51 kali dibandingkan di KBI. 


\section{KESIMPULAN}

Kesimpulan yang dapat ditarik dari penelitian ini yaitu akses penduduk berumur 16-30 tahun dalam hal layanan teknologi informasi dan komunikasi khususnya dalam hal penggunaan handphone dan pengunaan internet sudah cukup tinggi, namun masih cukup rendah dalam penggunaan PC/komputer/laptop. Bahkan, terdapat ketimpangan yang cukup tinggi terjadi pada akses PC/komputer/laptop. Jika dlihat berdasarkan kawasan di Indonesia, akses layanan informasi teknologi dan kumonikasi di KBI relatif lebih baik dibandingkan di KTI. Hal ini tentunya terkait dengan pembangunan infrastruktur Ti yang yang relatif lebih banyak dijumpai di KBI. Hasil dekomposisi ketimpangan kesempatan menunjukkan pengeluaran per kapita dan daerah tempat tinggal menjadi faktor yang dominan berpengaruh pada ketimpangan kesempatan. Oleh karena itu, penyediaan sarana infrastruktur TI diharapkan dapat menjangkau seluruh pelosok daerah sehingga akses TI lebih mudah diperoleh dengan murah dan mudah. Sementara itu, karakteristik sosial ekonomi penduduk yang mempunyai pengaruh terhadap akses penggunaan internet yaitu jenis kelamin individu, daerah tempat tinggal, jenis kelamin Kepala Rumah Tangga (KRT), pendidikan KRT, status bekerja KRT, jumlah ART, pengeluaran per kapita RT, penggunaan handphone, kepemilikan handphone, dan penggunaan PC/komputer/laptop. Penduduk laki-laki, penduduk perkotaan, penduduk di KBI mempunyai peluang yang lebih tinggi dalam hal akses penggunaan internet dibanding penduduk perempuan, penduduk perdesaan dan penduduk di KTI.

\section{Rekomendasi Penelitian Berikutnya}

Terdapat beberapa rekomendasi yang dapat dilakukan untuk penelitian berikutnya. Pertama, perlu dilakukan analisis dengan mengikutsertakan variabel infrastruktur sarana prasarana yang mendukung informasi teknologi dan komunikasi. Kedua, perlu menganalisis adanya perubahan waktu dengan menampilkan data time series.

\section{UCAPAN TERIMA KASIH}

Penulis R dan P.L. mengucapkan terima kasih kepada Kepala Subdirektorat Indikator Statistik yang telah memberikan saran dan masukan terkait penyusunan penelitian ini. Penulis juga mengucapkan terima kasih kepada BPS sebagai penyedia data dalam penelitian ini.

\section{DAFTAR PUSTAKA}

Arneson, R. (1989). Equality and Equal Opportunity for Welfare. Philosophical Studies: An International Journal for Philosophy in the Analytic Tradition, 56(1), 77-93.

De Barros, R. P., Ferreira, F. H., Vega, J. R., \& Chanduvi, J. S. (2009). Measuring Inequality of Opportunities in Latin America and the Caribbean.

De Soto, H. (2000). The Mystery of Capital: Why Capitalism Triumphs in the West and Fails Everywhere Else. Basic Books.

DiMaggio, P., \& Garip, F. (2012). Network Effects and Social Inequality. Annu. Rev. Social, 38, 93-118.

Dworkin, R. (1981). What is Equality? Part 1: Equality of Welfare. Philosophy \& Public Affairs, 10(3), 185246.

Indra. (2015). Empat Kajian Tentang: Polarisasi, Ketimpangan, dan Konflik Sosial di Indonesia. Universitas Indonesia.

Kemenppa, \& BPS. (2019). Kajian Ketimpangan Kesempatan Anak Terhadap Pelayanan Kebutuhan Dasar di Indonesia (Statistik Gender Tematik). Kemenppa.

Kominfo. (2014). Sekjen Kominfo: Perkembangan TIK, Berikan Manfaat Besar bagi Bidang Kehidupan. https://www.kominfo.go.id/content/detail/3960/sekjen-kominfo-perkembangan-tik-berikanmanfaatbesar-bagi-bidang-kehidupan/0/berita_satker

Rawls, J. (1971). A Theory of Justice. Harvard University Press.

Setiawati, N. L. P., \& Utomo, A. P. (2017). Model Regresi Logistik Untuk Melihat Pengaruh Faktor Demografis, Self Efficacy terhadap Perilaku Mencontek. JP3I, VI(2).

Sutton, R. E. (1991). Equity and Computers in the Schools: A Decade of Research. Review of Educational Research, Winter 1991, 61(4), 475-503.

Todaro, M. P., \& Smith, S. C. (2011). Pembangunan Ekonomi (11th ed.). Erlangga.

UNDP. (2014). Humanity Divided: Confronting Inequality in Developing Countries. UNDP. 
Zhu, J. J. H., \& He, Z. (2002). Diffusion, Use and Impact of The Internet in Hong Kong: A Chain Process Model. Journal of Computer Mediated Communication, 72), 1-26.

https://doi.org/https://doi.org/10.1111/j.1083-6101.2002.tb00139.x 